\title{
DEVELOPMENT COMPOSITE ALUMINIUM/FLY ASH WITH POWDER METALLURGY METHOD USE EGG YOLK AS SPACE HOLDER
}

\author{
AMIR ARIFIN ${ }^{1 *}$, GUNAWAN ${ }^{1}$, Alim MARdHI ${ }^{2}$, AgUng NURMANSAH PUTRA \\ WIJAYA ${ }^{1}$, ENDRA SUJATMIKA ${ }^{3}$ \\ ${ }^{1}$ Department of Mechanical Engineering, Universitas Sriwijaya, 30662 Indralaya, Sumatera \\ Selatan, Indonesia \\ ${ }^{2}$ Center for Nuclear Reactor Technology and Safety - BATAN \\ Nuclear Serpong Area, PUSPITEK complex Building 80th, South - T Banten, Indonesia \\ ${ }^{3}$ Faculty of Engineering and Built Enviroment, SEGi University, Taman Sains Selangor, \\ Damansara PJU 5, Petaling Jaya-47810, Selangor, Malaysia \\ .*Corresponding author:amir@unsri.ac.id
}

(Received: 18 November 2020; Accepted: 30 January 2021; Published on-line: 1 March 2021)

\begin{abstract}
:
Metal matrix composite has been used widely in some applications such as the automotive and aerospace industries. In this work, Aluminum/Fly ash composite material was made with an egg yolk space holder and the manufacturing process was successfully carried out. The process includes the mixing, stirring, drying, and sintering processes that were undertaken including the powder metallurgy method. The metal form has successfully been fabricated however the hardness test results for specimens were not very satisfactory. The Aluminum/Fly ash porous composite materials with egg yolk space holders were was characterized using XRay Florence (XRF), X-Ray Diffraction (XRD) test by producing the main peak of Al N and $\mathrm{Al}_{2} \mathrm{O}_{3}$. Observation of SEM by showing phenomena such as; cracks, alignment, and porous. Density Testing by producing an average porosity of $28.87 \%$. The observation of Optical Microscopes by showing the shape of the shaft that is not homogeneous.
\end{abstract}

KEYWORDS: Composite, Porous Material, Aluminum, Fly Ash, Powder Metallurgy

\section{INTRODUCTION}

Recently, many manufacturing companies are producing, innovating, and competing to find or create components, tools, and materials that can be used for various aspects such as good quality, strength, manufacturing costs, toughness, and others. These factors make a lot of research on developing composite materials. Composite materials are considered potential materials due to their mechanical properties because it has a lightweight and can perform at high temperatures [1-3].

A composite is a material that has a structural pattern formed from two or more materials that are combined into one, or a material that has two or more phases formed by a combination of matrix material and reinforcing material (reinforcement) [4]. The composite material combined with space holder material and have porous is porous composite material $[5][6][7][8][9]$.

The materials with many porous structures make it have advantages such as the capacity to absorb energy, thermal properties, and unique soundproofing [10][11][12][13][12]. The 
application of porous materials can be used in the automotive industry biomedical medical $[6,7][16]$.

The fabrication method of Aluminum/Fly ash composite materials using egg yolk as space holder material through the powder metallurgy route. The powder metallurgy route is a method to produce part through some stages. Commonly, the powder metallurgy stage is started mixing or blending stage, compaction stages, and finally sintering stages[8]. Occasionally, compaction and sintering stages are combined when the hot compaction method is used. The final product of powder metallurgy requires a secondary and finishing operation. The objective of this work is to investigate the feasibility fabrication of Aluminum/Fly ash composite through powder metallurgy using egg yolk as a space holder.

\section{METHODOLOGY}

The fabrication of Aluminum/Fly ash composite material with egg yolk as a space holder material is started with the mixing process of the raw material. In this work, aluminum powder is used as a matrix component and fly ash of coal combustion as reinforcement. To produce a porous structure egg yolk was used as a space holder. Furthermore, the mixing process of raw materials was performed using a magnetic stirrer. The mixing process was conducted for 2 and 3 hours to obtain a homogeny mixture. A slurry mixture was put into the cylinder molding to produce the green part. The green body was drying at $140^{\circ} \mathrm{C}, 160^{\circ} \mathrm{C}, 180^{\circ} \mathrm{C}$ with a holding time of 1 hour to reduce water content from the specimen. Fig. 1 shows the green body of the Aluminum/Fly ash composite.

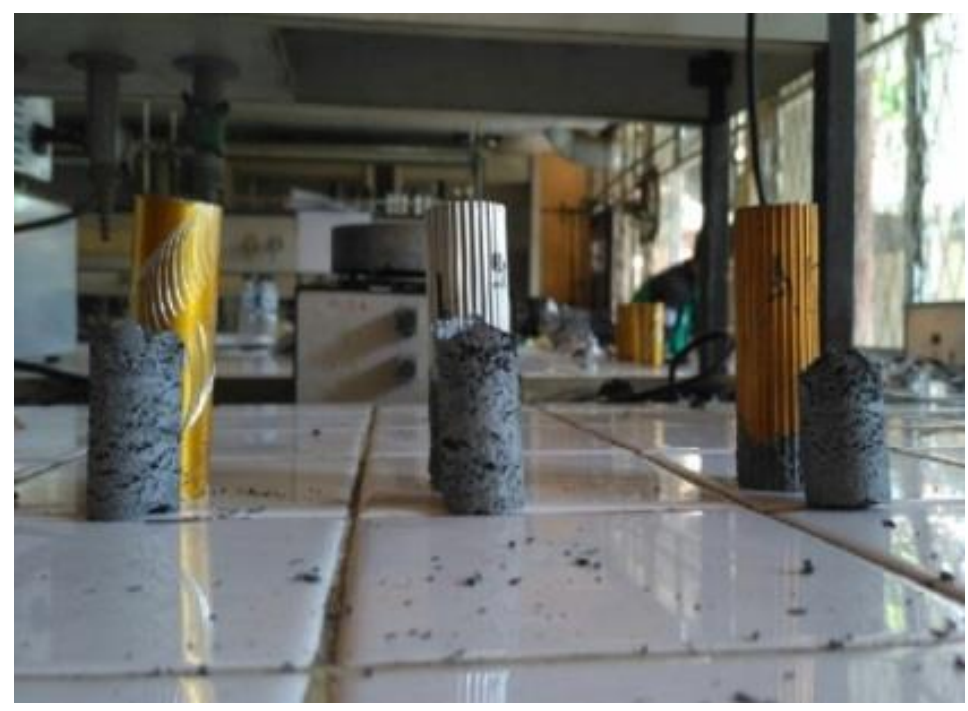

Fig. 1. Green body composite material Aluminum/Fly ash with egg yolk as a space holder

After the drying stage, sintering stages were conducted at $500^{\circ} \mathrm{C}$ with a holding time of 2 hours. The fabrication of Aluminum/Fly ash composite material with egg yolk as space holder has been performed. Moreover, some analysis and material characterization have been conducted such as the test of XRF, XRD, density, SEM, and optical microscope. 


\section{RESULTS}

The Aluminum/Fly ash composite material with egg yolk as space holder has been produced successfully. Water composition has a significant effect to determine the material properties of the specimen. Specimens tend to brittle with increasing of waters.

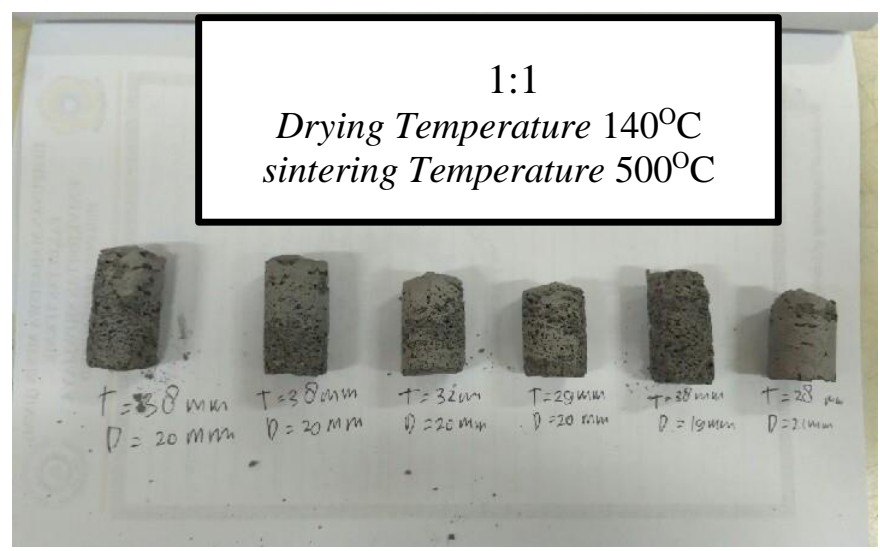

Fig. 2. Specimen failed 1

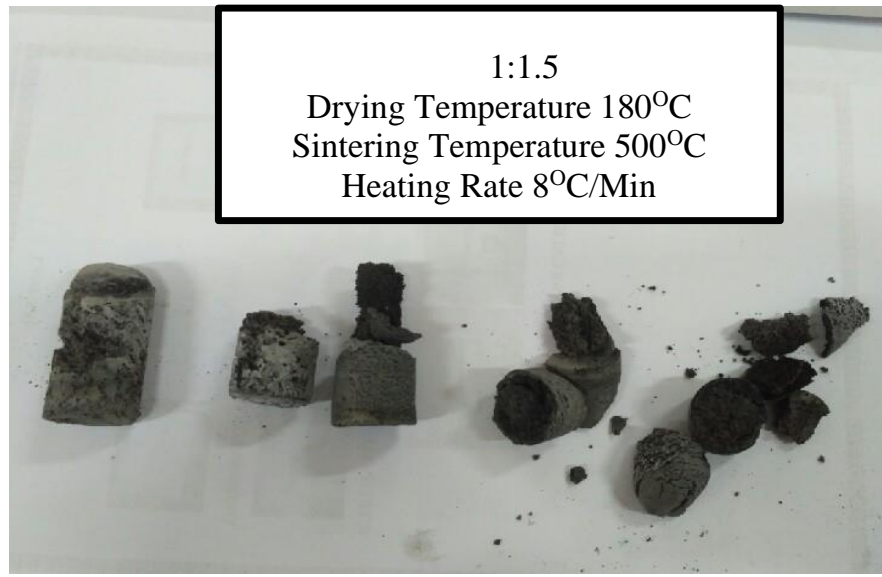

Fig. 3. Specimen failed 2

Fig. 2 and 3 show the Aluminum/Fly ash composite specimen which is unable to maintain its shape. Trial errors have been done to obtain a suitable amount of water. The stirring process was performed with water composition $10 \mathrm{ml}-20 \mathrm{ml}$ to obtain maximum results.

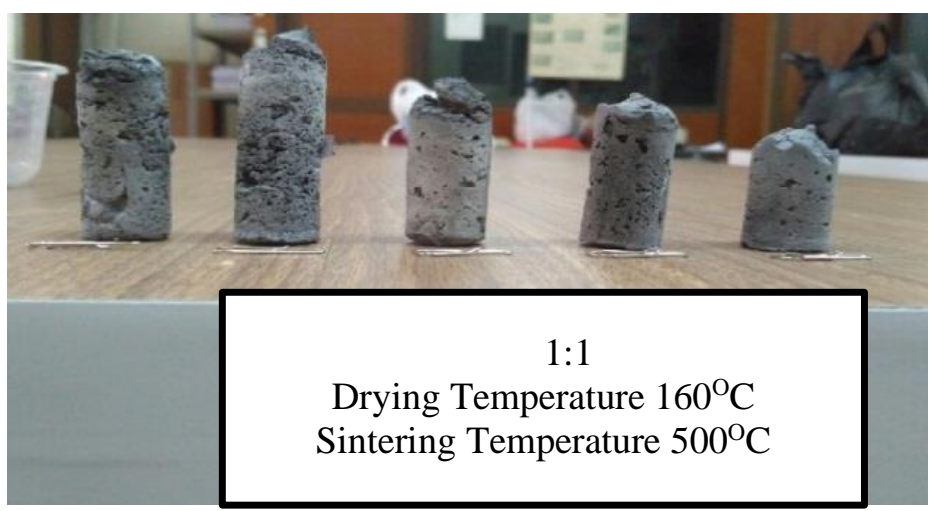

Fig. 4. Specimen with reducing water composition 
The XRF test that does for knowing chemical elements that the specimen container. For the step doing XRF test is to shoot X-rays through a Niton $\mathrm{X}_{12}$ device to the specimen to be tested then wait for some minute when the elements contained in the specimen will be seen, and the results of the XRF test on the Aluminum/Fly ash composite specimens with egg yolk as space holders are as elements: $\mathrm{Al} 98.48 \%, \mathrm{Cr} 0.099 \%, \mathrm{Mn} 0.089 \%, \mathrm{Fe} 0.763 \%, \mathrm{Cu} 0.128$ $\%$, Zn $0.320 \%$, Nb 0.061\%, Mo $0.037 \%$.

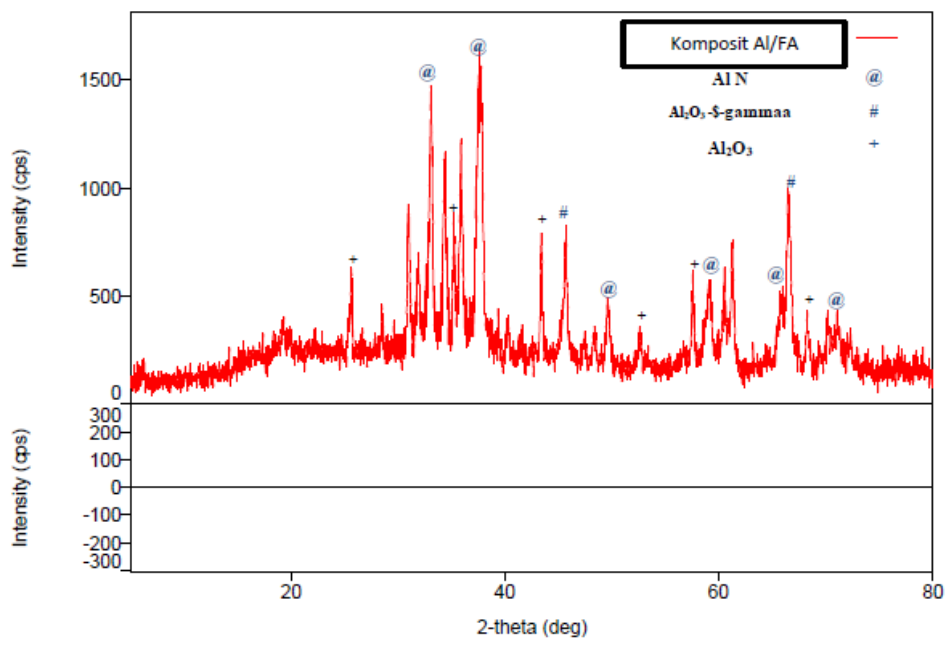

Fig. 5. XRD result for composite Al/FA with egg yolk as a space holder

The XRD test that does for knowing phases are formed in the specimen. Fig. 5 shows that the peak produced by the specimen test, there are a variety of 3 peaks produced such as Aluminum Nitride $(\mathrm{Al} \mathrm{N})$, Aluminum oxide gamma $\left(\mathrm{Al}_{2} \mathrm{O}_{3}\right)$, and Aluminum Oxide $\left(\mathrm{Al}_{2} \mathrm{O}_{3}\right)$. The Aluminum powder was used for the XRD test too and the result is the same as the XRD test Aluminum standard.

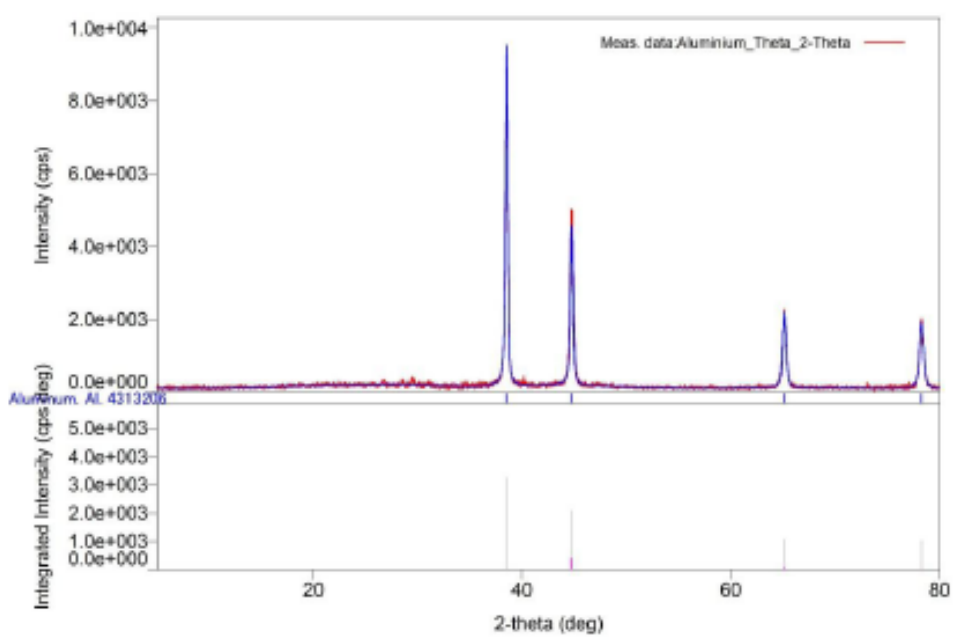

Fig. 6. XRD result for aluminum powder 


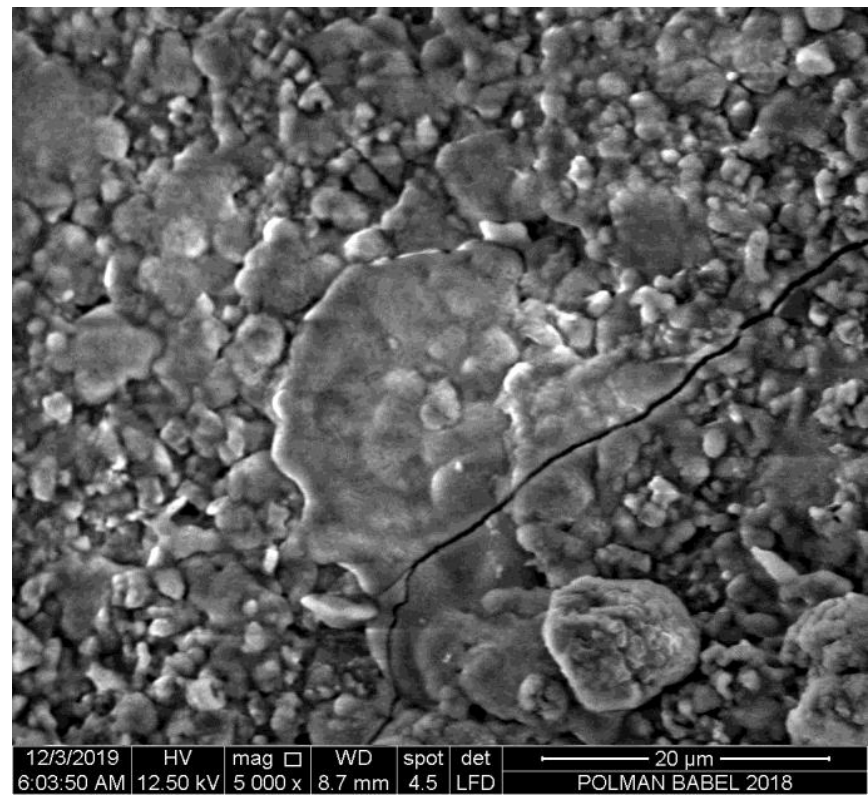

Fig. 7. SEM observations Al/FA with magnifications $5000 \mathrm{x}$.

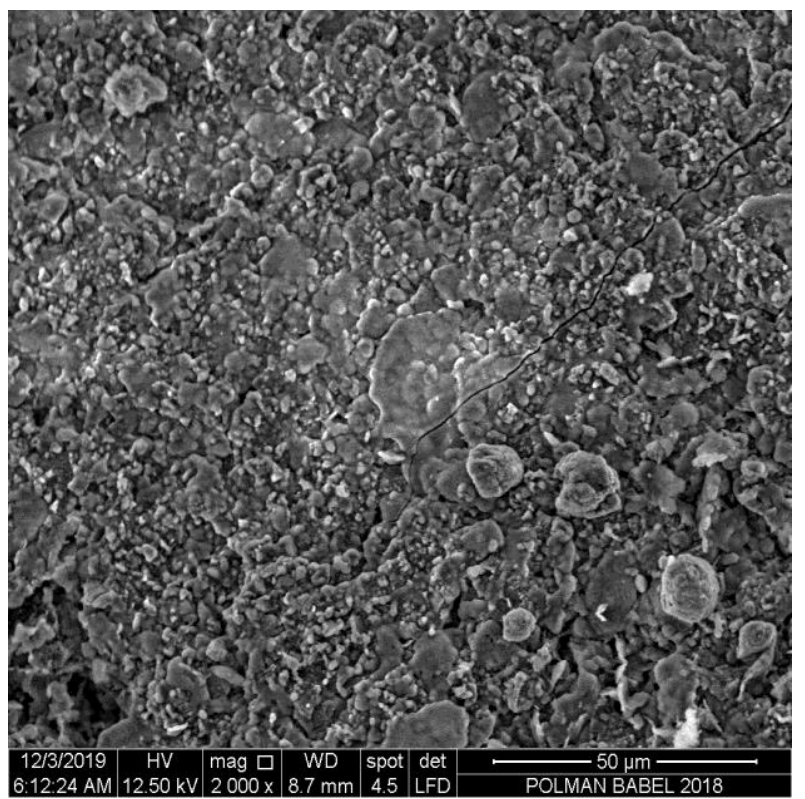

Fig. 8. SEM observations with magnifications $2000 \mathrm{x}$

A density test was carried out to determine the porosity that occurs in the specimen, and the results of the test in composite material aluminum/fly ash with egg yolk as space holder are shown average porosity number $28,6867 \%$.

Scanning Electron Microscopy Testing, SEM testing that has done aluminum/fly ash composite specimens is to determine the shape and morphology of the micro-scale specimens, the SEM observations this time used magnifications of $5000 \mathrm{x}, 2000 \mathrm{x}, 1000 \mathrm{x}$, and $250 \mathrm{x}$. The results of SEM observations are in Fig. 7. 


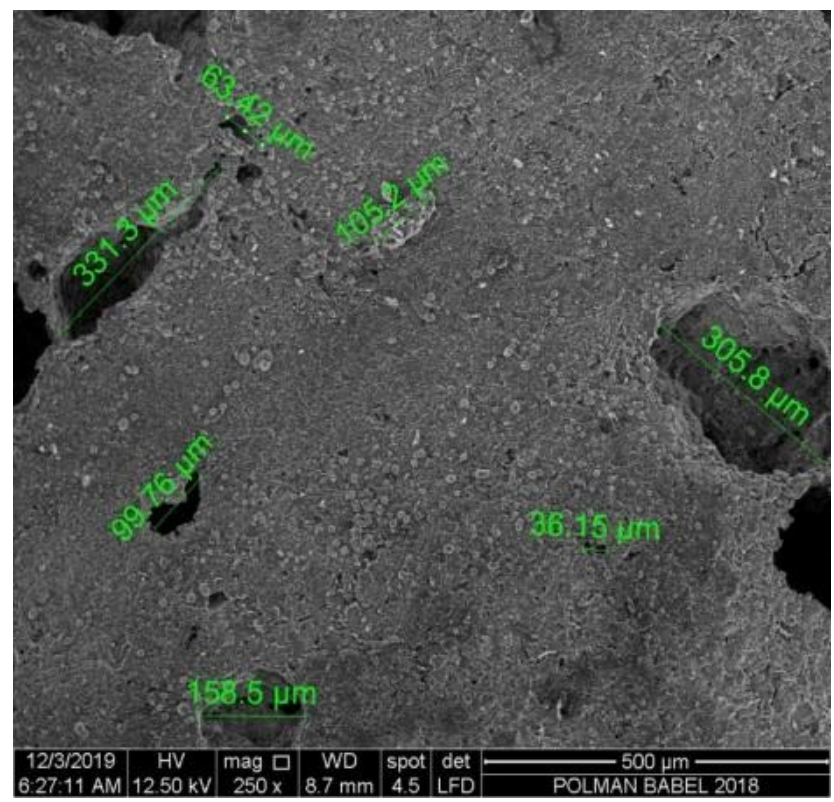

Fig. 9. SEM observations with magnifications $250 \mathrm{x}$.

Based on SEM analysis with magnifications of $5000 \mathrm{x}$ and $2000 \mathrm{x}$ have 3 phenomena, porous, cracks, and agglomeration while at 250x magnification, only 2 phenomena are seen, porous and agglomeration.

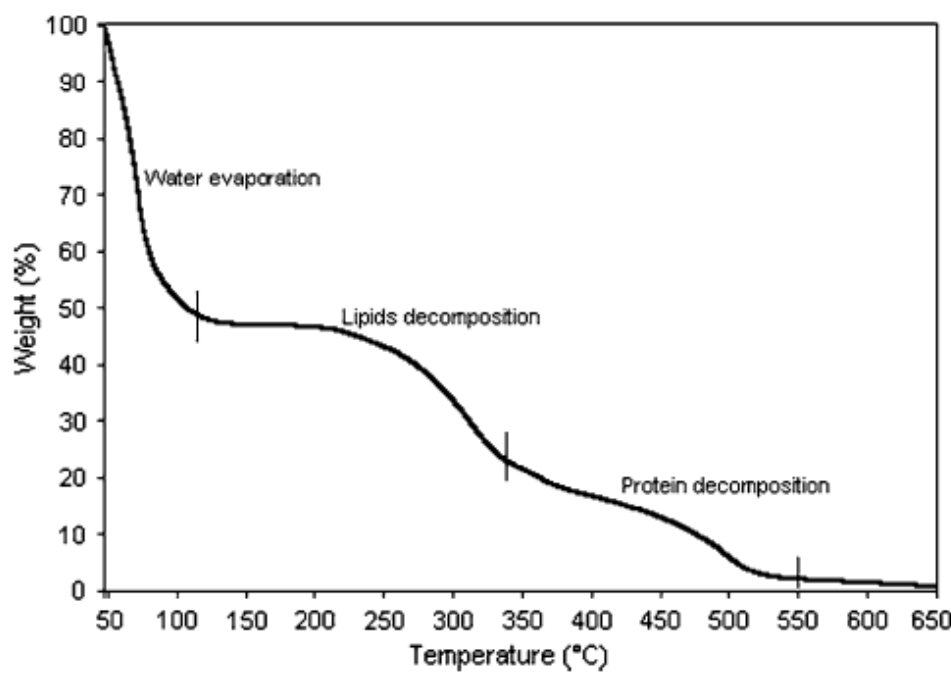

Fig. 10. TGA results for an egg yolk [7].

The porous structure has been observed as a result of the egg yolk space holder. Based on TGA analysis as shown in Fig. 10 yolk begins decomposed at $100{ }^{\circ} \mathrm{C}$ and $500{ }^{\circ} \mathrm{C}$ decomposed completely. Crack was observed on the surface was believed due to the high cooling rate.

Optical microscope observations, optical microscope observations that we do on Al / FA composite specimens with egg yolk as space holders are to determine the porous size produced by the specimens. For results from the optical microscope, observations are in Fig. 11. 


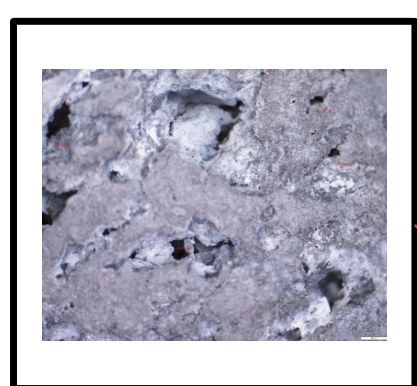

Point 4

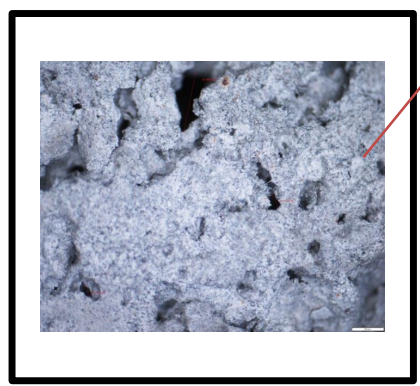

Point 6

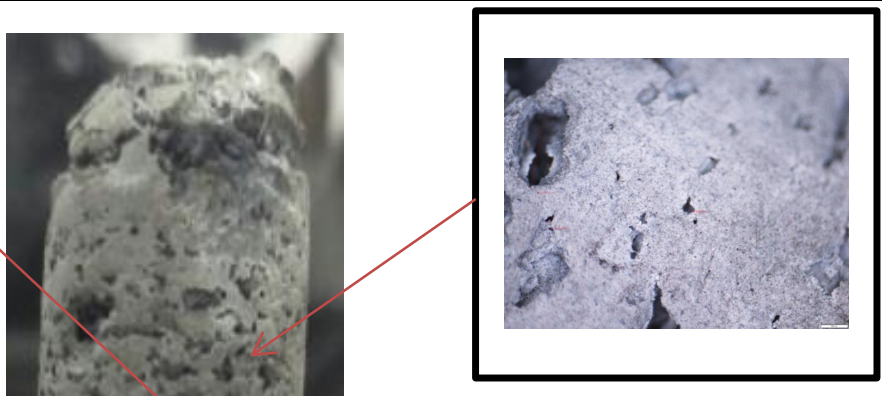

Point 5

Fig. 11. Observations optical microscope specimen

Fig. 11 to 13 show that the image of an optical microscope observation specimen with a magnification of 25 times and 30 times with observations at 3 points, to more clearly image magnification is as follows in Fig. 12.

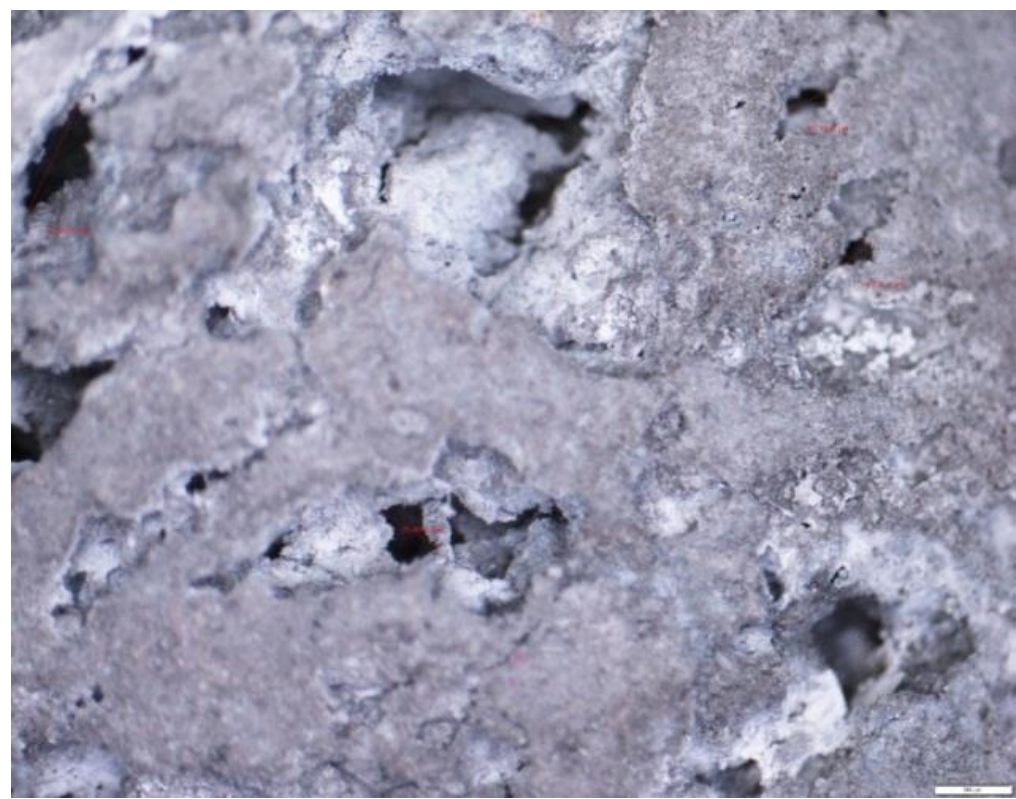

Fig. 12. Optical Microscope observations at point 4 with magnifications $25 \mathrm{x}$. 


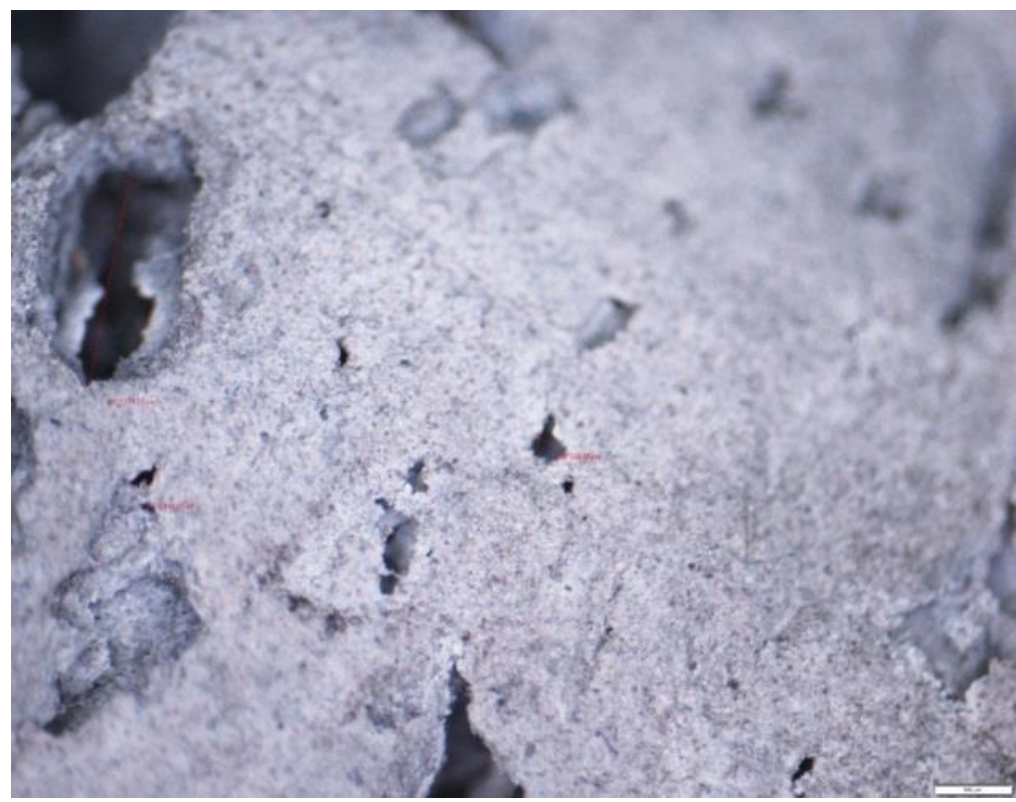

Fig. 13. Optical Microscope observations at point 5 with magnifications 25 x.

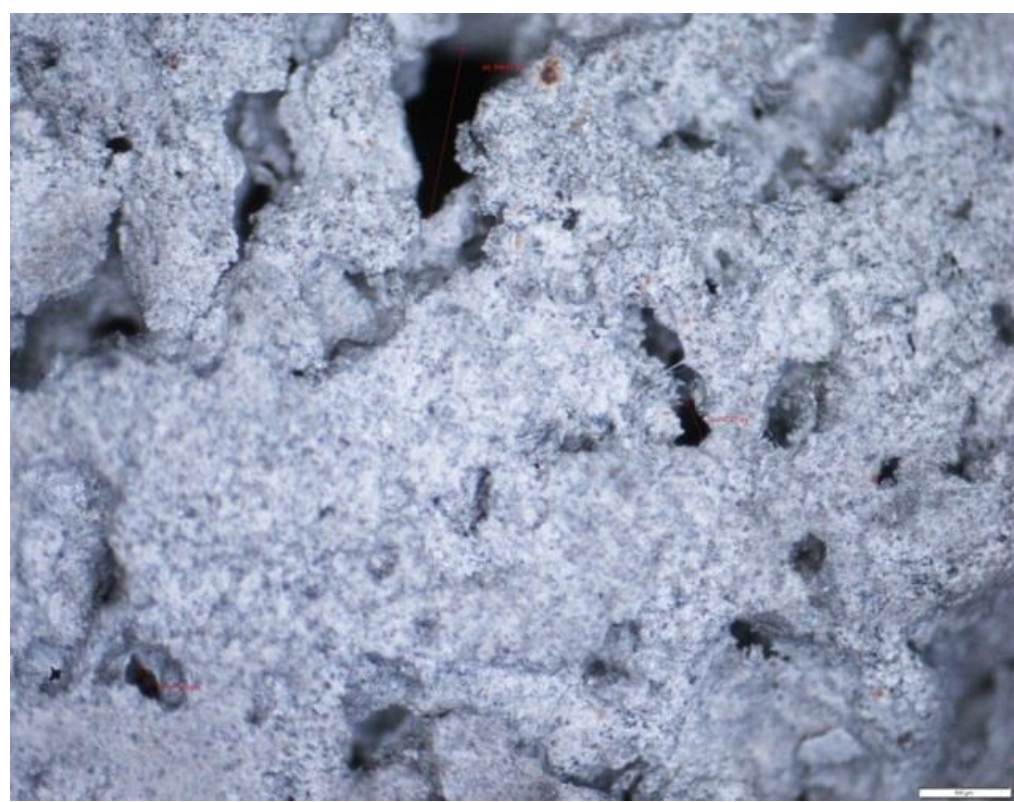

Fig. 14. Optical Microscope observations at point 6 with magnifications $30 \mathrm{x}$.

Fig. 14 shows that the porous size formed on the surface specimen is not homogeneous, it was believed due to the stirring process or the mixture of material used is not homogenous. The results produced are able to maintain their shape. However, the specimens are still brittle so they cannot produce high strength.

\section{CONCLUSION}

Based on analysis results, water composition is an important factor to determine mechanical properties. The materials tend to be brittle when the number of water increases. The homogeneity of the mixture is a significant factor to determine agglomeration of the slurry 
mixture which determines the success in the mixing process. The average porosity number is $28.85 \%$. for cracks occur because colling rate parameters are not used and when sintering at $500^{\circ} \mathrm{C}$ the space holder material still has a $10 \%$ weight and then other factors crack occur because the demolding process is not good.

\section{ACKNOWLEDGEMENT}

Thanks to Universitas Sriwijaya and the Center for Nuclear Reactor Technology and Safety (BATAN - Indonesia) for facilitating this research.

\section{REFERENCES}

[1] A. Arifin, R. Sipahutar, D. K. Pratiwi, I. Bizzy, D. W. I. Purba, and Gunawan, "Effect of fly ash as reinforcement on mechanical properties of aluminum scrap based hybrid composite," J. Eng. Sci. Technol., vol. 13, no. 10, 2018.

[2] A. Arifin, R. Sipahutar, D. K. Pratiwi, I. Bizzy, D. Purba, and Gunawan, "Effect of Fly Ash As Reinforcement on Mechanical Properties of Aluminum Scrap Based Hybrid Composite,” J. Eng. Sci. Technol., vol. 13, no. 10, pp. 3080-3091, 2018.

[3] G. Gunawan, A. Arifin, I. Yani, and M. Indrajaya, "Characterization of porous hydroxyapatite-alumina composite scaffold produced via powder compaction method," in IOP Conference Series: Materials Science and Engineering, 2019, vol. 620, no. 1, doi: 10.1088/1757-899X/620/1/012107.

[4] M. P. Groover, Fundamentals of Modern Manufacturing: Materials, Processes, and Systems. John Wiley \& Sons, 2010.

[5] A. Arifin, A. B. Sulong, L. C. Fun, Gunawan, and I. Yani, "Porous titanium alloy/hydroxyapatite composite using powder compaction route," J. Mech. Eng. Sci., vol. 11, no. 2, 2017, doi: 10.15282/jmes.11.2.2017.10.0244.

[6] Q. Z. Wang, C. X. Cui, S. J. Liu, and L. C. Zhao, "Open-celled porous Cu prepared by replication of $\mathrm{NaCl}$ space-holders," Mater. Sci. Eng. A, vol. 527, no. 4-5, pp. 12751278, 2010, doi: 10.1016/j.msea.2009.10.062.

[7] A. Arifin, G. Gunawan, and S. A. Chandra, "Fabrication Of Composite Copper/Fly Ash Foam With Egg Yolk as Foaming Agent," Indones. J. Eng. Sci., vol. 1, no. 1, pp. 001009, Jan. 2021, doi: 10.51630/ijes.v1i1.4.

[8] A. Arifin, Gunawan, A. Priyadi, and F. A. Sanjaya, "Development and characterization of porous hydroxyapatite-Alumina composite for engineering application," IOP Conf. Ser. Mater. Sci. Eng., vol. 857, p. 12005, 2020, doi: 10.1088/1757-899x/857/1/012005.

[9] Gunawan, A. Arifin, I. Yani, and S. D. Arian, "The Fabrication Porous hydroxyapatite Scaffold Using Sweet Potato Starch as a Natural Space Holder," in Journal of Physics: Conference Series, 2019, vol. 1198, no. 4, doi: 10.1088/1742-6596/1198/4/042020.

[10] A. Wijaya, B. Eichinger, M. Mischitz, and R. Brunner, "3D Characterization of Porous Copper Thin Films," Microsc. Microanal., vol. 25, no. S2, pp. 348-349, Aug. 2019, doi: 10.1017/S1431927619002472.

[11] Gunawan, A. Arifin, M. Reza, and A. N. P. Wijaya, "Development of aluminum matrix composite with hybrid reinforcement using stir casting route," in IOP Conference 
Series: Materials Science and Engineering, 2020, vol. 857, no. 1, doi: 10.1088/1757899X/857/1/012007.

[12] S. Trushad, W. Kuruneru, K. Vafai, E. Sauret, and Y. Gu, "Application of porous metal foam heat exchangers and the implications of particulate fouling for energy-intensive industries," Chem. Eng. Sci., vol. 228, p. 115968, 2020, doi: 10.1016/j.ces.2020.115968.

[13] C. Y. Zhao, "Review on thermal transport in high porosity cellular metal foams with open cells," Int. J. Heat Mass Transf., vol. 55, no. 13-14, pp. 3618-3632, 2012, doi: 10.1016/j.ijheatmasstransfer.2012.03.017.

[14] H. Zhao et al., "Compact 3D Copper with Uniform Porous Structure Derived by Electrochemical Dealloying as Dendrite-Free Lithium Metal Anode Current Collector," Adv. Energy Mater., vol. 8, no. 19, p. 1800266, Jul. 2018, doi: 10.1002/aenm.201800266.

[15] B. Bian et al., "Application of 3D printed porous copper anode in microbial fuel cells," Front. Energy Res., vol. 6, no. JUN, 2018, doi: 10.3389/fenrg.2018.00050.

[16] M. Niinomi, "Mechanical biocompatibilities of titanium alloys for biomedical applications," J. Mech. Behav. Biomed. Mater., vol. 1, no. 1, pp. 30-42, 2008, doi: 10.1016/j.jmbbm.2007.07.001. 